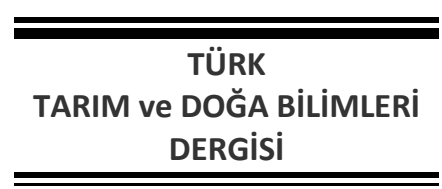

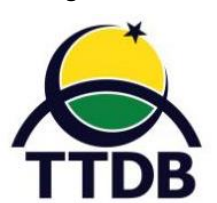

www.dergipark.gov.tr/turkjans

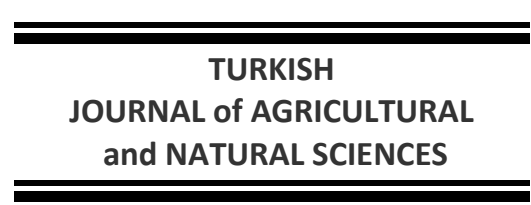

OURNAL OF AGRICULTURAL and NATURAL SCIENCES

Araştırma Makalesi

\title{
Farklı Lokasyonlarda Yetiştirilen Bazı Mürdümük (Lathyrus sativus L.) Genotiplerinin Tarımsal Özellikleri
}

\author{
Mustafa DENiZ ${ }^{1}$, Serap KIZIL AYDEMiR ${ }^{2}$, Elvin ALGAN ${ }^{1}$, Duran Ümit YERLiKAYA ${ }^{1}$, Ayşen UZUN ${ }^{1 *}$ \\ ${ }^{1}$ Bursa Uludağ Üniversitesi Ziraat Fakültesi Tarla Bitkileri Bölümü \\ ${ }^{2}$ Bilecik Şeyh Edebali Üniversitesi Ziraat ve Doğa Bilimleri Fakültesi Tarla Bitkileri Bölümü \\ *Sorumlu yazar: uzunay@uludag.edu.tr
}

Geliş Tarihi: 26.11.2019 Düzeltme Geliş Tarihi: 08.05.2020 Kabul Tarihi: 08.05.2020

\begin{abstract}
Özet
Bazı mürdümük (Lathyrus sativus L.) genotiplerinin tarımsal özelliklerini belirlenmek için yapılan bu çalışma, Bilecik ve Bursa ekolojik koşullarında gerçekleştirilmiştir. Araştırmada tarla denemeleri, 20172018 gelişme döneminde Bursa Uludağ Üniversitesi Ziraat Fakültesi Tarımsal Uygulama ve Araştırma Merkezi ile Bilecik Şeyh Edebali Üniversitesi Ziraat ve Doğa Bilimleri Fakültesi Tarımsal Uygulama ve Araştırma Merkezi'nde kışlık olarak yürütülmüştür. Araştırmada 5 adet mürdümük çeşidi (Eren, Gap Mavisi, Gürbüz 2001, İptaş ve Karadağ) ile 1 adet köy popülasyonu kullanılmıştır. Araştırma denemeleri Tesadüf Blokları Deneme Deseni'ne göre üç tekrarlamalı olarak kurulmuştur. Araştırmada incelenen özelliklerde genotip x lokasyon interaksiyon ortalamalarında; yeşil ot veriminde $1711.51-4420.00 \mathrm{~kg} \mathrm{da}^{-1}$, kuru madde veriminde 390.93-790.01 kg da ${ }^{-1}$, ottaki ham protein oranında \% 11.90-20.23, ottaki ham protein veriminde 46.53-157.99 kg da-1, ADF oranında \% 27.00-39.83, NDF oranında \% 34.07-44.96, bitkideki tohum sayısında 23.33-112.67 adet, bitkideki bakla sayısında 8.87-54.67 adet, 1000 tane ağırlığında $137.61-189.40 \mathrm{~g}$, tohum veriminde $52.28-186.33 \mathrm{~kg} \mathrm{da}^{-1}$, tohumdaki ham protein oranında \% 22.47-28.05 ve tohumdaki ham protein veriminde $12.18-44.17 \mathrm{~kg} \mathrm{da}^{-1}$ arasında değişim gözlenmiştir. Araştırma sonucuna göre; mürdümük genotiplerinde ot verimi, tohum verimi ve diğer verim parametreleri bakımından Bilecik lokasyonunda elde edilen değerler, Bursa lokasyonunda elde edilen değerlere göre daha yüksek bulunmuştur. Her iki lokasyonda da ot ve tohum verimi bakımından Eren ve İptaş çeşitlerinin diğer genotiplere göre daha üstün olduğu tespit edilmiştir.
\end{abstract}

Anahtar Kelimeler: Mürdümük, Lathyrus sativus L., kuru madde verimi, tohum verimi, 1000 tane ağırlığı

\section{Agricultural Characteristics of Some Grasspea (Lathyrus sativus L.) Genotypes} Growing at Different Locations

\footnotetext{
Abstract

This study was carried out in order to determine the agricultural characteristics of some grasspea (Lathyrus sativus L.) genotypes in Bilecik and Bursa ecological conditions. Field experiments were conducted in 2017-2018 growth period at Bursa Uludag University, Faculty of Agriculture, and Bilecik Şeyh Edebali University, Faculty of Agriculture and Natural Sciences Agricultural Research and Application Centers as a winter. Five grasspea cultivars (Eren, Gap Mavisi, Gürbüz 2001, İptaş ve Karadağ) and one population were used in this research. The experiments were established according to the randomized complete block design with three replications. In genotype $\mathrm{x}$ location interactions of characteristics examined in this research, forage yield, dry matter yield, forage crude protein rate, forage crude protein yield, ADF and NDF rates, seed numbers in plant, seed number in pod, 1000 seed weight, seed yield, seed crude protein rate and seed crude protein yield were determined between $1711.51-4420.00 \mathrm{~kg} \mathrm{da}^{-1}$, $390.93-790.01 \mathrm{~kg} \mathrm{da}^{-1}$, \% 11.90-20.23, 46.53-157.99 kg da-1, \% 27.00-39.83, \% 34.07-44.96, 23.33-112.67 number, 8.87-54.67 number, 137.61-189.40 g, 52.28-186.33 kg da-1, \% 22.47-28.05 and 12.18-44.17 kg $\mathrm{da}^{-1}$, respectively. All of characteristics examined have higher values in Bilecik location than Bursa location
} 
in research. Eren and Iptaş varieties were found to be superior in term of forage and seed yield in both locations.

Key words: Grasspea, Lathyrus sativus L.,, dry matter yield, seed yield, 1000 seed weight

\section{Giriş}

Yem bitkileri hayvanların yem ihtiyacını karşılamanın yanı sıra toprakların fiziksel ve kimyasal özelliklerini iyileştirmekte, kendisinden sonra gelen kültür bitkilerinin verim ve kalitesini olumlu yönde etkilemekte, özellikle baklagil yem bitkileri yeşil gübreleme amacıyla kullanılmakta ve fikse ettiği azot ile ana bitkinin ihtiyacı olan azot gereksiniminin önemli bir kısmını sağlamakta, erozyona açık alanları çok iyi bir şekilde değerlendirmektedir. Hayvanların yem ihtiyacı karşılanırken yıllardan beri yaygın olarak yonca, fiğ, korunga gibi sınırlı sayıda baklagil yem bitkisi kullanılmaktadır. Oysa hem yem bitkisi üretimini arttırmak hem de farklı alanları değerlendirebilmek için alternatif yem bitkilerine de tarla tarımı içerisinde yer verilmesi gerekmektedir. Bu yüzden, Ülkemiz'de birçok alanda yetiştirilebilecek yem bitkilerinden biri de mürdümük (Lathyrus sativus L.)'tür. Mürdümük baklagil familyasına ait tek yıllık bir bitkidir. Hayvan beslenmesinin yanında insan beslenmesinde de kullanılır (Başaran ve ark., 2011; Mihailovic ve ark., 2013). Hem otundaki (\%17-22) hem de tohumundaki (\%25-36) protein içeriği oldukça yüksektir; hastalıklara dayanımı iyidir, yetiştiriciliği oldukça kolaydır (Rosa ve ark., 2000; Urga ve ark., 2005). Yıllık yağışı 250$300 \mathrm{~mm}$ olan yerlerde otu, samanı veya tanesi için yetiştirilen, kuraklığa en fazla dayanan bitkilerden birisidir (Öten ve ark., 2017). Gelişmekte olan ülkelerdeki kurak alanlarda, tarımın sürdürülebilirliği için önemli bir bitkidir ve bu alanlarda mürdümükten ekonomik bir verim almak mümkündür (Vaz Patto ve ark., 2006; Arslan, 2016). Mürdümük kuraklığa dayanıklı olmasının yanı sıra aşırı yağıştan etkilenmez ve fazla sulu alanlarda da yetişebilir (Urga ve ark., 2005). Özellikle kuraklığa dayanıklılı̆ı, kötü koşulları değerlendirmesi, toprağı azotça zenginleştirmesi, yetiştiriciliğinde çok fazla girdiye ihtiyaç duymaması ve hayvan beslenmede kullanılmasının yanı sıra tanelerinin insan beslenmesinde de kullanılması nedeniyle mürdümük Ülkemiz'de çok eski yıllardan beri bilinen ve yetiştiriciliği yapılan bir bitkidir. TUik (2018) verilerine göre; Türkiye'de mürdümük (Lathyrus sativus L.) ekim alanı 136507 dekar olup ot üretim miktarı 98238 ton, tane üretim miktarı da 860 tondur. Yeşil ot verimi ortalama olarak $769 \mathrm{~kg} \mathrm{da}^{-1}$, tane verimi de $100 \mathrm{~kg} \mathrm{da}^{-1}$ dır.
Türkiye'de en fazla mürdümük Adıyaman, Balıkesir, Diyarbakır, Elazığ, Kahramanmaraş, Kütahya, Tunceli ve Uşak illerinde yetiştirilmektedir. Mürdümük, genellikle kışlık olarak ekilmektedir. Farklı yerlerde yapılan bu ekimlerde, çevreye bağı olarak büyük verim farklılıkları elde edilmektedir. Bir genotipin verimini tam olarak belirleyebilmek için farklı çevrelerde denenmesi gerekmektedir.

Bu çalışmada; 5 adet mürdümük çeşidi (Gap Mavisi, Gürbüz 2001, Karadağ, İptaş ve Eren) ile 1 adet mürdümük köy popülasyonu (Tekirdağ) 2 lokasyonda (Bursa ve Bilecik) denemeye alınmıştır. Farklı lokasyonlarda yapılan denemeler ile genotiplerin bazı agro-morfolojik ve kalite özelliklerinin belirlenmesi amaçlanmıştır.

\section{Materyal ve Yöntem}

$\mathrm{Bu}$ araştırma 2017-2018 yetişme sezonunda, Bursa'da Uludağ Üniversitesi Ziraat Fakültesi ile Bilecik'te Bilecik Şeyh Edebali Üniversitesi Ziraat ve Doğa Bilimleri Fakültesi Tarımsal Uygulama ve Araştırma Merkezleri'nde kışlık olarak yürütülmüştür. Denemelerde materyal olarak Bilecik Şeyh Edebali Üniversitesi Ziraat ve Doğa Bilimleri Fakültesi'den sağlanan Eren, Gap Mavisi, Gürbüz-2001, İptaş, Karadağ çeşitleri ile Tekirdağ Namık Kemal Üniversitesi Tarla Bitkileri Bölümü'nden temin edilen bir köy populasyonu kullanılmıştır. Bu çeşitlerden Gürbüz-2001 Tarla Bitkileri Merkez Araştırma Enstitüsü, Eren, İptaş ve Karadağ Gazi Osman Paşa Üniversitesi Ziraat Fakültesi ve Gap Mavisi de GAP Uluslararası Tarımsal Araştırma ve Eğitim Merkezi Müdürlüğü tarafından tescil edilmiştir. Araştırmanın yapıldığı yılda, bitki gelişim döneminde (Kasım-Haziran) Bilecik lokasyonunda düşen toplam yağış miktarı 367.8 $\mathrm{mm}$ iken Bursa lokasyonunda $569.2 \mathrm{~mm}$ olmuştur. Aynı dönemde Bilecik'teki ortalama sıcaklık $11.6{ }^{\circ} \mathrm{C}$ iken Bursa' da bu sıcaklık $13.7{ }^{\circ} \mathrm{C}$ olarak belirlenmiştir. Oransal nem değerleri ise Bilecik ve Bursa lokasyonlarında sırası ile \% 72.4 ve \% 75.2 olmuştur. Bilecik ve Bursa lokasyonlarında uzun yıllar ortalamasına ait değerlerde toplam yağışın sırasıyla 361.3-558.3 $\mathrm{mm}$; ortalama sıcaklığın $9.3-11.5{ }^{\circ} \mathrm{C}$ ve ortalama oransal nemin de \% 69.6-71.0 olduğu tespit edilmiştir (Çizelge 1) (Anonim 2018). 
Çizelge 1. Bilecik ve Bursa Illleri'nde Denemenin Yürütüldüğü Yıla ve Uzun Yıllara Ait Toplam Yağış (mm), Ortalama Sıcaklık $\left({ }^{0} \mathrm{C}\right)$ ve Oransal Nem (\%) Değerleri

\begin{tabular}{|c|c|c|c|c|c|c|c|c|c|c|}
\hline \multirow{2}{*}{$\begin{array}{c}\text { İklim } \\
\text { Faktörleri }\end{array}$} & \multirow{2}{*}{ Yıllar } & \multicolumn{8}{|c|}{ Aylar } & \multirow{2}{*}{$\begin{array}{c}\text { Top./ } \\
\text { Ort. }\end{array}$} \\
\hline & & $11^{*}$ & 12 & 1 & 2 & 3 & 4 & 5 & 6 & \\
\hline \multirow{4}{*}{ Yağış (mm) } & Bilecik & 21.1 & 63.2 & 40.9 & 37.6 & 66.1 & 18.6 & 80.8 & 39.5 & 367.8 \\
\hline & $\begin{array}{l}\text { Uzun } \\
\text { Yıllar }\end{array}$ & 37.2 & 55.9 & 50.1 & 42.0 & 47.3 & 41.8 & 47.7 & 39.3 & 361.3 \\
\hline & Bursa & 37.4 & 109.0 & 67.6 & 97.2 & 92.2 & 15.4 & 91.0 & 59.4 & 569.2 \\
\hline & $\begin{array}{l}\text { Uzun } \\
\text { Yıllar }\end{array}$ & 74.4 & 101.8 & 92.5 & 78.4 & 70.3 & 59.2 & 50.4 & 31.3 & 558.3 \\
\hline \multirow{4}{*}{ Sicaklık $\left({ }^{0} \mathrm{C}\right)$} & Bilecik & 8.9 & 6.7 & 4.0 & 7.3 & 10.8 & 16.0 & 18.2 & 21.2 & 11.6 \\
\hline & $\begin{array}{l}\text { Uzun } \\
\text { Yıllar }\end{array}$ & 8.6 & 4.5 & 2.6 & 3.6 & 6.7 & 11.6 & 16.2 & 20.8 & 9.3 \\
\hline & Bursa & 11.0 & 9.5 & 6.7 & 9.6 & 13.2 & 15.8 & 19.9 & 23.5 & 13.7 \\
\hline & $\begin{array}{l}\text { Uzun } \\
\text { Yıllar }\end{array}$ & 12.2 & 7.6 & 5.3 & 6.3 & 8.3 & 12.8 & 17.5 & 22.2 & 11.5 \\
\hline \multirow{4}{*}{$\begin{array}{c}\text { Oransal } \\
\text { Nem } \\
(\%)\end{array}$} & Bilecik & 74.0 & 77.4 & 80.9 & 79.7 & 70.2 & 57.0 & 72.5 & 67.3 & 72.4 \\
\hline & $\begin{array}{l}\text { Uzun } \\
\text { Yillar }\end{array}$ & 71.1 & 76.0 & 76.5 & 73.2 & 69.3 & 64.2 & 64.5 & 62.0 & 69.6 \\
\hline & Bursa & 78.5 & 76.2 & 78.3 & 79.0 & 72.2 & 70.8 & 76.5 & 70.1 & 75.2 \\
\hline & $\begin{array}{l}\text { Uzun } \\
\text { Yillar }\end{array}$ & 74.3 & 73.6 & 75.0 & 73.1 & 72.2 & 69.5 & 68.8 & 61.3 & 71.0 \\
\hline
\end{tabular}

*: 11=Kasım; 12=Aralık; 1= Ocak; 2= Şubat; 3= Mart; 4= Nisan; 5= Mayıs; 6= Haziran

Toprak analiz sonuçlarına göre deneme alanının Bilecik Ili'nde kumlu tınlı bünyeli, orta alkali ve orta tuzlu, kireççe orta düzeyde, organik madde içeriği orta, alınabilir fosfor ve potasyum bakımından az olduğu; Bursa ilii'nde de; killi-tınlı bünyeli, tuzsuz, hafif alkali, kireççe orta seviyede, organik madde içeriği orta, alınabilir fosfor ve potasyum bakımından çok yüksek olduğu belirlenmiştir. Bilecik ve Bursa lokasyonlarında yürütülmüş olan bu araştırma üç tekrarlamalı olarak Tesadüf Blokları Deneme Deseni'ne göre gerçekleştirilmiştir. Araştırmada deneme ekimleri açılan çizilere el ile yapılmıştır. Deneme ekim tarihleri Bilecik lokasyonunda 02.11.2017 ve Bursa lokasyonunda da 07.11.2017 tarihinde gerçekleşmiştir. Denemelerde, T.C. Tarım ve Orman Bakanlığı Bitkisel Üretim Genel Müdürlüğü'nün Baklagil Yem Bitkileri Tarımsal Değerleri Ölçme Denemeleri Teknik Talimatnamesi'ne göre $\mathrm{m}^{2 \prime}$ ye 100 adet tohum gelecek şekilde ekim normu ayarlanmıştır. Her iki lokasyonda da parsel uzunluğu $5 \mathrm{~m}$, bir parseldeki sıra sayısı 6 adet ve sıra arası mesafesi $20 \mathrm{~cm}$ olmuştur. Denemelere ekim ile birlikte dekara $3 \mathrm{~kg} \mathrm{da}^{-1}$ saf azot hesabı ile gübre atılmıştır. Deneme alanlarında 2 kez el ile yabancı otlar temizlenmiş, tohum böceği zararına karşı çiçeklenme döneminde 10 gün arayla 2 kez ilaçlama yapılmıştır. Yeşil ot için hasat, bitkilerin alt baklalarındaki taneler iz şeklinde görüldüğü dönemde gerçekleştirilmiştir. Denemelerde parsellerin yarısı ota yarısı da tohuma biçilmiştir. Tohum için hasat Bilecik lokasyonunda 30.06.2018, Bursa lokasyonundada 05.07.2018 tarihlerinde olmuş ve tohumlar Bruchus zararlısına karşı fostoksin ile fümige edilmiştir. Araştırmadan elde edilen veriler JUMP paket programından yararlanılarak tesadüf blokları deneme desenine göre analiz edilmiştir (Turan, 1995). Ortalamalar arasındaki farklılıklar ve istatistiki farklı gruplar asgari 
önemli farklılık (LSD) testiyle 0.01 ve 0.05 olasılık düzeyinde belirlenmiştir.

\section{Bulgular ve Tartışma}

Bilecik ve Bursa lokasyonlarında denenen mürdümük genotiplerinin ot ve tohum verimi ile bazı kalite özellikleri incelenmiştir.

Ot ile İlgili Özellikler: Yapılan bu çalışmada; yeşil ot ve kuru madde verimi, ham protein oranı ve verimi ile ADF ve NDF değerleri üzerine genotip, lokasyon ve genotip $\mathrm{x}$ lokasyon interaksiyonu istatistiki anlamda \%1 olasılık düzeyinde önemli bulunmuştur.

Yeşil ot verimi $\left(\mathbf{k g} \mathbf{d a}^{-1}\right)$ : Denemede kullanılan genotipler arasında, lokasyonlar ortalamasına göre yeşil ot verimi en fazla $4255.02 \mathrm{~kg} \mathrm{da}^{-1}$ ile İptaş çeşidinden elde edilmiş, en düşük yeşil ot verimi de $2589.09 \mathrm{~kg} \mathrm{da}^{-1}$ ile Gürbüz-2001 çeşidinde belirlenmiştir. Bilecik lokasyonunda elde edilen yeşil ot verimi $3892.22 \mathrm{~kg} \mathrm{da}^{-1}$ ile Bursa lokasyonundan fazla olmuştur (Çizelge 2). Deneme yılında, bitki gelişim döneminde ve çiçeklenme dönemi olan Nisan-Mayıs aylarında Bursa'daki toplam yağış (106.4 mm) Bilecik (99.4 $\mathrm{mm})^{\prime}$ ten fazla olurken ortalama sıcaklık Bursa $\left(17.9{ }^{\circ} \mathrm{C}\right)$ 'da Bilecik $\left(17.1{ }^{\circ} \mathrm{C}\right)$ 'ten daha yüksek belirlenmiştir. Özellikle Bursa'da Mayıs ayında görülen 91.0 mm'lik yağış ile meydana gelen göllenmeler yeşil ot veriminin düşmesine neden olmuştur. Ayrıca; yine çiçeklenme ve tozlanma zamanındaki $19.9{ }^{\circ} C^{\prime}$ lik sıcaklık da bitki gelişimini, Bursa lokasyonunda olumsuz etkilemiştir (Çizelge 1). Bazı araştırıcılar yüksek sıcaklıkların bitkilerde solunumu arttırdığını, yapraklardaki çözülebilir karbonhidrat yoğunluğunu azalttığını ve bunun sonucunda da bitkilerde verim düşüklüğünün ortaya çıktığını belirtmişlerdir (Arevalo ve ark., 2008; Loka ve Oosterhuis, 2010). Yapılan bu çalışmada da özellikle Şubat, Mart, Nisan ve Mayıs aylarında Bilecik lokasyonunda maksimum sıcaklıklar sırasıyla 18.3, 23.7, 30.3 ve $30.8{ }^{\circ} \mathrm{C}$ olarak belirlenmiş ve bu değerler Bursa lokayonuna ait 21.0, 26.0, 29.3 ve $33.9{ }^{\circ} \mathrm{C}$ değerlerinden düşük olmuştur. Tüm bu nedenlerden dolayı yeşil ot verimleri Bursa lokasyonunda daha az olarak tespit edilmiştir. Genotip $x$ lokasyon interaksiyonuna bakıldığında en yüksek yeşil ot veriminin sırasıyla Bilecik lokasyonunda İptaş ve Eren çeşitlerinde, Bursa lokasyonunda ise yine İptaş çeşidinde olduğu görülmüştür. Gürbüz2001 'in Bursa lokasyonunda yeşil ot verimi ise en düşük olmuştur. Hem Bilecik hem de
Bursa'da, en yüksek yeşil ot verimi İptaş'tan, en düşük yeşil ot verimi de Gürbüz-2001'den elde edilmiştir (Çizelge 2). Daha önce yapılan araştırmalarda Karadağ ve ark (2012) (2175.2 $\left.2582.5 \mathrm{~kg} \mathrm{da}^{-1}\right)$, Mihailovic ve ark., (2013) (2340.0-5070.0 kg da-1) ile Sayar ve ark. (2013)'nın (2140.0-3711.0 kg da-1) mürdümük genotiplerinde saptamış oldukları yeşil ot verimine ilişkin değerler, bulgularımızla tam uyumlu bulunmuştur. Bunun yanı sıra Sabancı ve ark. (2016) (330.5-423.5 kg da-1) ile Öten ve ark. (2017) (1622.5 kg da-1) yaptıkları çalışmalarda yeşil ot verimini daha düşük bulmuşlardır. Denemelerin yapıldığı ekolojilerin ve kullanılan çeşitlerin farklı olması, hasat zamanlarındaki değişiklik, denemelerin yazlık veya kışlık olarak yapılması yeşil ot verimlerinin de farklı olmasına neden olmuştur.

Kuru madde verimi ( $k g$ da $\left.{ }^{-1}\right)$ : Her iki lokasyon ortalama değerlerine göre İptaş (660.37 kg da-1) ve Eren ( $\left.639.36 \mathrm{~kg} \mathrm{da}^{-1}\right)$ çeşitlerinin kuru madde verimleri diğer genotiplerden daha yüksek olarak bulunmuştur (Çizelge 2). Bilecik lokasyonundan daha fazla kuru madde verimi elde edilmiştir. Çiçeklenme döneminde Bursa lokasyonunda yağışların ve sıcaklığın fazlalığı verimin düşmesine neden olmuştur. Bilecik lokasyonunda Eren çeşidinde $790.01 \mathrm{~kg} \mathrm{da}^{-1}$ ile en yüksek kuru madde verimi belirlenirken $736.98 \mathrm{~kg} \mathrm{da}^{-1}$ ile İptaş çeşidi de aynı gruba girmiştir. En düşük kuru madde verimleri Bursa lokasyonundaki genotiplerden elde edilmiştir. Mürdümük ile yapılan çalışmalarda kuru madde verimini; Karadağ ve ark. (2012) 600.7-743.3 kg $\mathrm{da}^{-1}$, Sayar ve ark. (2013) 600.7-743.3 kg da-1 ile Seydoşoğlu ve ark. (2015) 336.1-767.4 kg da-1 olarak belirtmişlerdir.

Ham protein oranı (\%): Genotiplerin ortalama ham protein oranları \% 15.12-17.72 arasında değişirken en yüksek ham protein oranı Populasyon'da belirlenmiştir. \% 19.49 ile Bilecik lokasyonundaki ham protein oranı, Bursa lokasyonundan yüksek olmuştur. Genotip x lokasyon interaksiyonunda ham protein oranları \%11.90-20.23 arasında değişmiş ve Bilecik lokasyonunda Gürbüz çeşidi ile Populasyon hariç diğer tüm çeşitler en yüksek değerleri vermişlerdir (Çizelge 2). Bitkilerin vejetasyon dönemlerinde; özellikle Ocak, Şubat, Mart ve Mayıs aylarında Bursa lokasyonunda (sırasıyla 67.6, 97.2, 92.2 ve $91.0 \mathrm{~mm}$ ) Bilecik lokasyonuna (sırasıyla 40.9, 37.6, 66.1 ve 80.8 $\mathrm{mm}$ ) oranla yağış miktarının yüksek olması Bursa 
lokasyonunda protein oranlarının düşmesine neden olmuştur (Çizelge 1). Nitekim Sabancı ve ark. (2016) yaptıkları çalışmada; fazla yağışın mürdümük ham protein oranını düşürdüğünü bildirmişlerdir. Aynı şekilde Acar ve ark. (1997) vejetasyon döneminde düşen fazla yağışın ham protein oranını düşürdüğünü açıklamışlardır. Çalışmamızda elde edilen verilere benzer olarak, mürdümükte Larbi ve ark. (2010) \% 19.30-21.20, Kosev ve Vasileva (2018) \% 10.12-10.96 arasında değişen ham protein oranları belirlemişlerdir.

Ham protein verimi $\left(\mathbf{k g ~ d a}^{-1}\right)$ : Eren (112.79 $\mathrm{kg}$ $\mathrm{da}^{-1}$ ) ve İptaş (111.49 $\mathrm{kg} \mathrm{da}^{-1}$ ) genotiplerinden elde edilen ortalama ham protein verimleri en yüksek olmuştur. Bilecik lokasyonundan 134.12 $\mathrm{kg} \mathrm{da}^{-1}$ ve Bursa lokasyonundan da $62.88 \mathrm{~kg} \mathrm{da}^{-1}$ ham protein verimi elde edilmiştir. Bilecik lokasyonunda Eren çeşidinde en yüksek ham protein verimi belirlenmiştir. Tüm genotipler Bursa lokasyonunda Bilecik'e göre daha düşük değerler vermiştir (Çizelge 2). Ham protein oranının yanısıra kuru madde veriminin de düşük olması Bursa lokasyonunda ham protein veriminin de düşmesine neden olmuştur.

Kökten ve Tansı (2004) yaptıkları çalışmada mürdümük otunda ham protein verimini 123.39 $\mathrm{kg} \mathrm{da}^{-1}$ olarak bulurken Sabancı ve ark. (2016) bu değerin 18.8-32.2 $\mathrm{kg} \mathrm{da}^{-1}$ arasında değiştiğini bildirmişlerdir. Araştırmaların yapıldığı ekolojik koşulların ve kullanılan genotiplerin farklılığı sonuçlar arasındaki farklılığın ortaya çıkmasına neden olmuştur.

ADF (Asit Deterjanda Çözünmeyen Lif) (\%): Çizelge 2'de genotiplerin ortalama ADF oranlarının \% 29.90-34.78 arasında değiştiği görülmektedir. En düşük $A D F$ değeri Eren çeşidinden elde edilirken en yüksek ADF değeri de Gürbüz-2001 çeşidinden elde edilmiştir. Bursa lokasyonunda belirlenen ADF oranı Bilecik lokasyonundan daha yüksek olmuştur. Genotip x lokasyon interaksiyonunda görüldüğü gibi Bilecik lokasyonunda Karadağ çeşidi en düşük ADF oranına sahip olurken Bursa lokasyonundaki genotiplerin ADF değerleri yüksek olmuştur. Vejetasyon döneminde lokasyonlar arasında görülen yağış rejimindeki farklılıkların bu sonuçlara sebep olduğu düşünülmektedir. Hücre duvarı bileşenleri olan ve sindirimi azaltan ADF ve NDF seviyelerinin artması, hayvanların tokluk hissetmesine neden olmakta ve hayvanların yem tüketimini azaltmaktadır (Van Soest 1994, Yavuz
2005). Bu nedenle kaliteli yem için ADF ve NDF oranlarının düşük olması istenmektedir. Yaptı̆̆ımız çalışmada elde ettiğimiz ADF oranlarına benzer şekilde, Karadağ ve ark. (2011)'ı da bu değerin \% 33.9-39.0 arasında değiştiğini açıklamışlardır. Ancak Sabancı ve ark. (2016) ise yaptıkları bir çalışmada ADF oranını \% 22.9-25.7 olarak belirlemişlerdir.

NDF (Nötr Deterjanda Çözünmeyen Lif) (\%): En düşük ortalama NDF oranı \% 37.31 ile İptaş çeşidinde belirlenmiştir. Bilecik lokasyonundan elde edilen NDF değeri Bursa lokasyonundan daha az olmuştur. Genotip x lokasyon interaksiyonunda ise NDF değerleri \% 34.0744.96 arasında değişmiş ve Bilecik lokasyonunda Karadağ, İptaş ve Gap Mavisi aynı gruba girerek en düşük değerleri vermişlerdir (Çizelge 2). NDF değerlerinin yüksek olması yemin az sindirildiğini gösterir. NDF değeri yüksek olan yemlerle beslenen hayvanlar tokluk hisseder ve daha az yem ile beslenirler (Van Soest, 1994; Yavuz, 2005). Elde edilen sonuçlara benzer olarak yaptıkları çalışmada Karadağ ve ark. (2011) mürdümükte NDF oranının \% 42.6-51.2 arasında değiştiğini bildirirken Sabancı ve ark. (2016) bu oranı daha düşük olarak açıklamışlardır (\% 28.8-31.4).

Tohum ile ilgili Veriler: Bitkideki tohum sayısı üzerine genotipler, bitkideki bakla sayısı üzerine de genotip x lokasyon interaksiyonu $\% 5$ olasılık düzeyinde önemli bulunmuş, bitkideki tohum sayısı üzerine interaksiyonun etkisi önemsiz olmuştur. Diğer tüm özellikler üzerine ise genotip, lokasyon ve genotip $\mathrm{x}$ lokasyon interaksiyonu istatistiki anlamda \%1 olasılık düzeyinde önemli olarak tespit edilmiştir.

Tohum/Bitki (adet): Genotiplerde ortalama bitkideki tohum sayısı 59.00-82.90 adet arasında değişmiş ve tohum sayısı en fazla Eren çeşidinde belirlenirken onu aynı gruba giren Karadağ ve Iptaş çeşitleri takip etmiştir. Bilecik lokasyonunda elde edilen tohum sayısı Bursa lokasyonundan daha fazla olmuştur (Çizelge 3). Mikic ve ark. (2010) mürdümük ile yaptıkları bir araştırmada bitkideki tohum sayısını ortalama olarak 36.90 adet olarak bulurken Kökten ve Bakoğlu (2011) 31.70 adet olarak belirlemişlerdir. 
Çizelge 2. Farklı lokasyonlardaki mürdümük genotiplerine ait yeşil ot verimi, kuru madde verimi, ham protein oranı, ham protein verimi, ADF ve NDF değerleri.

\begin{tabular}{|c|c|c|c|c|c|c|}
\hline \multirow{2}{*}{$\begin{array}{l}\text { Genotip/ } \\
\text { Lokasyon }\end{array}$} & Bilecik & Bursa & Genotip Ort. & Bilecik & Bursa & $\begin{array}{c}\text { Genotip } \\
\text { Ort. }\end{array}$ \\
\hline & \multicolumn{3}{|c|}{ Yeşil Ot Verimi $\left(\mathrm{kg} \mathrm{da}^{-1}\right)$} & \multicolumn{3}{|c|}{ Kuru Madde Verimi (kg da $\left.{ }^{-1}\right)$} \\
\hline Eren & $4400.00 a^{*}$ & $3540.20 \mathrm{bc}$ & 3970.10 B & $790.01 \mathrm{a}$ & $488.71 \mathrm{f}$ & $639.36 \mathrm{~A}$ \\
\hline Gap mavisi & $3716.67 \mathrm{~b}$ & $2894.17 \mathrm{e}$ & $3305.42 \mathrm{C}$ & $682.51 \mathrm{~cd}$ & $398.50 \mathrm{~g}$ & $540.51 \mathrm{~B}$ \\
\hline Gürbüz-2001 & $3466.67 \mathrm{bc}$ & $1711.51 \mathrm{f}$ & $2589.09 \mathrm{D}$ & $563.00 \mathrm{e}$ & $390.93 \mathrm{~g}$ & $476.97 \mathrm{C}$ \\
\hline İptaş & $4420.00 \mathrm{a}$ & $4090.03 \mathrm{a}$ & $4255.02 \mathrm{~A}$ & $736.98 \mathrm{ab}$ & $583.75 \mathrm{e}$ & $660.37 \mathrm{~A}$ \\
\hline Karadağ & $3616.67 \mathrm{~b}$ & $3276.27 \mathrm{~cd}$ & $3446.47 \mathrm{C}$ & $645.34 \mathrm{~d}$ & $431.11 \mathrm{~g}$ & $538.23 \mathrm{~B}$ \\
\hline Populasyon & $3733.33 \mathrm{~b}$ & $3107.51 \mathrm{de}$ & $3420.42 \mathrm{C}$ & $701.35 \mathrm{bc}$ & $426.63 \mathrm{~g}$ & $563.99 \mathrm{~B}$ \\
\hline $\begin{array}{l}\text { Lokasyon } \\
\text { Ort. }\end{array}$ & $3892.22 \mathrm{~A}$ & $3103.28 \mathrm{~B}$ & & $686.53 \mathrm{~A}$ & $453.27 \mathrm{~B}$ & \\
\hline LSD (0.05) & L:171.39 & 35.80 & 33.47 & L:43.71 & LxG:5 & \\
\hline
\end{tabular}

Ham Protein Oranı (\%)

Ham Protein Verimi $\left(\mathrm{kg} \mathrm{da}^{-1}\right)$

\begin{tabular}{lccc|ccc}
\hline Eren & $20.00 \mathrm{a}$ & $13.82 \mathrm{ef}$ & $16.91 \mathrm{~B}$ & $157.99 \mathrm{a}$ & $67.59 \mathrm{ef}$ & $112.79 \mathrm{~A}$ \\
Gap mavisi & $19.63 \mathrm{ab}$ & $14.38 \mathrm{e}$ & $17.01 \mathrm{~B}$ & $133.95 \mathrm{c}$ & $57.33 \mathrm{fg}$ & $95.64 \mathrm{~B}$ \\
Gürbüz-2001 & $18.33 \mathrm{c}$ & $11.90 \mathrm{~g}$ & $15.12 \mathrm{C}$ & $103.19 \mathrm{~d}$ & $46.53 \mathrm{~g}$ & $74.86 \mathrm{C}$ \\
İptaş & $19.83 \mathrm{a}$ & $13.13 \mathrm{f}$ & $16.48 \mathrm{~B}$ & $146.23 \mathrm{~b}$ & $76.75 \mathrm{e}$ & $111.49 \mathrm{~A}$ \\
Karadağ & $20.23 \mathrm{a}$ & $13.59 \mathrm{ef}$ & $16.91 \mathrm{~B}$ & $130.63 \mathrm{c}$ & $58.69 \mathrm{f}$ & $94.65 \mathrm{~B}$ \\
Populasyon & $18.93 \mathrm{bc}$ & $16.50 \mathrm{~d}$ & $17.72 \mathrm{~A}$ & $132.71 \mathrm{c}$ & $70.37 \mathrm{e}$ & $101.54 \mathrm{~B}$ \\
Lokasyon & $19.49 \mathrm{~A}$ & $13.89 \mathrm{~B}$ & & $134.12 \mathrm{~A}$ & $62.88 \mathrm{~B}$ & \\
Ort. & L:0.41 G:0.58 LxG:0.82 & & L:7.34 G:8.23 & LxG:11.64 \\
LSD (0.05) & & & &
\end{tabular}

\begin{tabular}{lccc|ccc}
\multicolumn{9}{c}{ ADF (\%) } \\
\hline Eren & $29.77 \mathrm{e}$ & $30.04 \mathrm{e}$ & $29.90 \mathrm{E}$ & $36.27 \mathrm{e}$ & $40.68 \mathrm{~b}$ & $38.47 \mathrm{C}$ \\
Gap mavisi & $27.93 \mathrm{fg}$ & $39.55 \mathrm{a}$ & $33.74 \mathrm{~B}$ & $35.03 \mathrm{f}$ & $44.57 \mathrm{a}$ & $39.80 \mathrm{~B}$ \\
Gürbüz-2001 & $29.73 \mathrm{e}$ & $39.83 \mathrm{a}$ & $34.78 \mathrm{~A}$ & $37.7 \mathrm{~d}$ & $44.56 \mathrm{a}$ & $41.13 \mathrm{~A}$ \\
İptaş & $28.23 \mathrm{f}$ & $34.99 \mathrm{~b}$ & $31.61 \mathrm{D}$ & $34.83 \mathrm{f}$ & $39.79 \mathrm{bc}$ & $37.31 \mathrm{D}$ \\
Karadağ & $27.00 \mathrm{~g}$ & $38.76 \mathrm{a}$ & $32.88 \mathrm{C}$ & $34.07 \mathrm{f}$ & $44.96 \mathrm{a}$ & $39.52 \mathrm{~B}$ \\
Populasyon & $31.73 \mathrm{~d}$ & $33.16 \mathrm{C}$ & $32.45 \mathrm{CD}$ & $37.17 \mathrm{de}$ & $39.42 \mathrm{c}$ & $38.29 \mathrm{C}$ \\
Lokasyon Ort. & $29.07 \mathrm{~B}$ & $36.06 \mathrm{~A}$ & & $35.84 \mathrm{~B}$ & $42.33 \mathrm{~A}$ & \\
LSD (0.05) & L:0.80 G:0.85 & LxG:1.21 & & L:0.42 G:0.73 & LxG:1.04 \\
\hline
\end{tabular}

*: Aynı harfleri taşıyan ortalamalar arasındaki fark önemli değildir ( $P<0.05)$ (LSD)

Bakla/Bitki (adet): Eren çeşidinde ortalama bitkideki bakla sayısı 36.17 adet ile en fazla olarak belirlenmiştir. Bitkideki bakla sayısı Bilecik lokasyonunda Bursa lokasyonundan fazla olmuştur. Eren çeşidi Bilecik'te 54.67 adet bakla vermişken Bursa lokasyonundaki tüm çeşitlerin bakla sayıları az olmuştur (Çizelge 3). Daha önce yapılan çalışmalarda, mürdümükte bitkideki bakla sayıları ortalama olarak Milczak ve ark. (2001) tarafından 19.8 adet, Mikic ve ark. (2010) tarafından 15.5 adet ve Kökten ve Bakoğlu (2011) tarafından da 18.1 adet olarak belirtilmiştir. 
1000 tane ağırlığı (g): Çizelge 3'de görüldüğü gibi genotiplerin 1000 tane ağırlıkları 140.74$173.68 \mathrm{~g}$ arasında değişmiş göstermiş̧tir. İptaş ve Eren çeşitlerinin 1000 tane ağırlıkları en yüksek olup en düşük 1000 tane ağırlığına Gürbüz-2001 çeşidi sahip olmuştur. Bilecik lokasyonunda, bitkilerin 1000 tane ağırlıkları $164.57 \mathrm{~g}$, Bursa lokasyonunda ise $156.41 \mathrm{~g}$ olmuştur. $189.40 \mathrm{~g}$ ile Populasyon Bursa lokasyonunda, $187.47 \mathrm{~g}$ ile Iptaş Bilecik lokasyonunda en yüksek değerlere ulaşmışlardır. Genellikle tüm çeşitlerin 1000 tane ağırlıkları Bursa'da daha az olmuştur. Tohum veriminde belirtildiği gibi Bursa'daki ekolojik olaylar 1000 tane ağırlığııın düşük olmasına neden olmuştur. Türkiye'de değişik lokasyonlarda, farklı mürdümük genotipleri ile yapılan çalışmalarda tohumların 1000 tane ağırlıkları 72.2-204.5 g arasında değişmiştir (Kökten ve Bakoğlu., 2011; Sayar ve Han 2015; Seydoşoğlu ve ark., 2015; Öten ve ark., 2017).

Tohum verimi ( $\left.\mathrm{kg} \mathrm{da}^{-1}\right)$ : Genotiplerde ortalama tohum verimi $107.97-153.69 \mathrm{~kg} \mathrm{da}^{-1}$ arasında olmuş ve en yüksek tohum verimi Eren çeşidinden elde edilmiştir. Lokasyonlardaki tohum verimi incelendiğinde Bilecik'te elde edilen tohum veriminin daha fazla olduğu görülmektedir (Çizelge 3). Lokasyonlar arasındaki tohum verimi farkının, özellikle çiçeklenme ve döllenmenin olduğu Nisan ve Mayıs aylarında, Bilecik lokasyonundaki oransal nemin (sırasıyla \%57.0 ve \%72.5), Bursa lokasyonundaki oransal nemden (sırasıyla \%70.8 ve \% 76.5) düşük olmasından kaynaklandığı düşünülmektedir (Çizelge 1). Sağsöz (1990); tohum üretiminde bitkilerin çiçeklenme ve tozlanma döneminde düşük oransal nem istediğini ve bitkilerin bu koşullarda daha kolay tozlanma gerçekleştirdiklerini açıklamıştır. Ayrıca Karadağ ve Yavuz (2010)'a göre; mürdümükte tohum verimindeki düşüklüğün başlıca nedeni; özellikle çiçeklenme dönemindeki kuraklıktır. Bu kuraklık, döllenmeden sonra çiçeklerde ve baklalarda dökülmeye sebep olmaktadır. Bilhassa baklagil yem bitkilerinde, çiçeklenme döneminden tohum oluşumuna kadar geçen süredeki su ihtiyacı çok önemlidir (Barnes ve ark., 2003). Nitekim yaptı̆̆ımız çalışmada; Bursa lokasyonunda bitkilerin çiçeklenme döneminde
(Nisan ayı) yağışın az olması (15.4 mm) nedeniyle tohum verimi daha düşük olmuştur. Ayrıca çiçeklenmenin devam ettiği Mayıs ayındaki fazla yağış $(91.0 \mathrm{~mm})$ ve yüksek sıcaklık $\left(19.9^{\circ} \mathrm{C}\right)$ da bu düşüşü devam ettirmiştir (Çizelge 1). Genotip $x$ lokasyon genotipi incelendiğinde en yüksek tohum verimi Eren çeşidinde Bilecik lokasyonunda belirlenmiştir. En düşük tohum verimi de Gürbüz-2001 çeşidinde Bursa lokasyonunda elde edilmiştir (Çizelge 3). Yaptıkları çalışmada Bayram ve ark. (2004) mürdümükte tohum verimini $67.3-202.9 \mathrm{~kg} \mathrm{da}^{-1}$ olarak bulurken Seydoşoğlu ve ark. (2015) bu değerin 181.0-269.8 $\mathrm{kg} \mathrm{da}^{-1}$ arasında değiştiğini bildirmişlerdir. Diğer taraftan Öten ve ark. (2017)'nın açıkladığına göre mürdümükte ortalama tohum verimi $355.0 \mathrm{~kg} \mathrm{da}^{-1}$ olmuştur.

Ham protein oranı (\%):Populasyon'un ortalama ham protein oranı \% 5.26 ile en yüksek olmuş, bunu aynı gruba giren İptaş (\% 24.80) ve Gürbüz2001 (\% 24.27) çeşitleri takip etmiştir. Eren ve Gap Mavisi'nin ise ham protein oranları en düşük olmuştur. Bilecik lokasyonunda ham protein oranı \% 24.94, Bursa lokasyonunda \% 23.06 olarak belirlenmiştir. Bilecik lokasyonunda Populasyon'dan elde edilen ham protein oranı en yüksek değere ulaşmış ve Bursa lokasyonunda tüm genotiplerden elde edilen ham protein oranı da en az olmuştur (Çizelge 3). Yaptıkları çalışmalarda; mürdümükteki ham protein oranını Urga ve ark. (2005) \% 29.64, Kosev ve Vasileva (2018) \% 25.27 olarak belirlemişlerdir.

Ham protein verimi $\left(\mathbf{k g} \mathbf{d a}^{-1}\right)$ : Eren çeşidinin ortalama ham protein veriminin en yüksek olduğu ve bunu aynı gruba giren Karadağ çeşidinin takip ettiği Çizelge 3'de görülmektedir. Bilecik'te elde edilen ham protein verimi 38.71 kg da-1 iken Bursa'da $23.39 \mathrm{~kg} \mathrm{da}^{-1}$ olmuştur. Genotip x lokasyon interaksiyonuna bakıldığında Bilecik'te İptaş ve Eren çeşitleri ham protein verimi açısından en yüksek değerlere ulaşmış, bu çeşitleri yine Bilecik'te aynı gruba giren Gürbüz2001 çeşidi takip etmiştir. Ham protein verim değerleri Bursa'da tüm genotiplerde düşük olmuştur. 
Çizelge 3. Farklı lokasyonlardaki mürdümük genotiplerine ait tohum/bitki, bakla/bitki, tohum verimi, 1000 tane ağırlığı, ham protein oranı ve ham protein verimi değerleri.

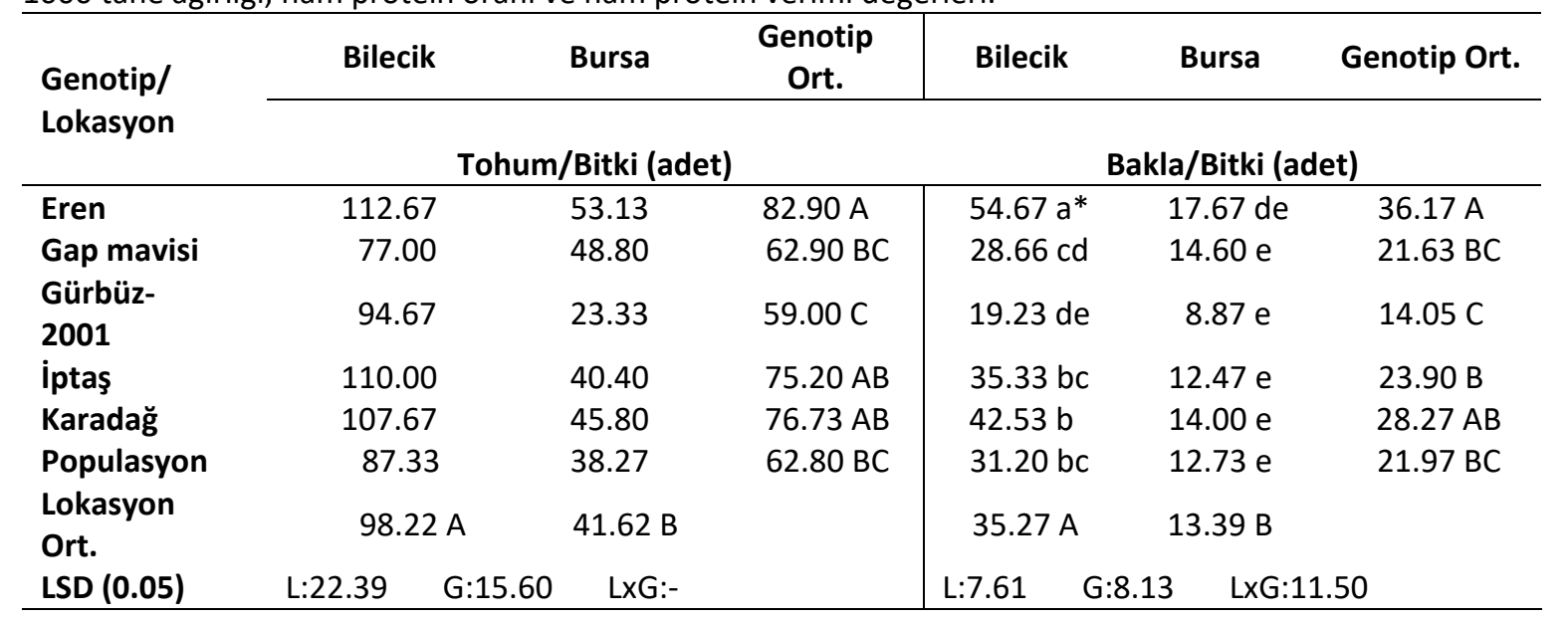

1000 Tane Ağırlığı (g)

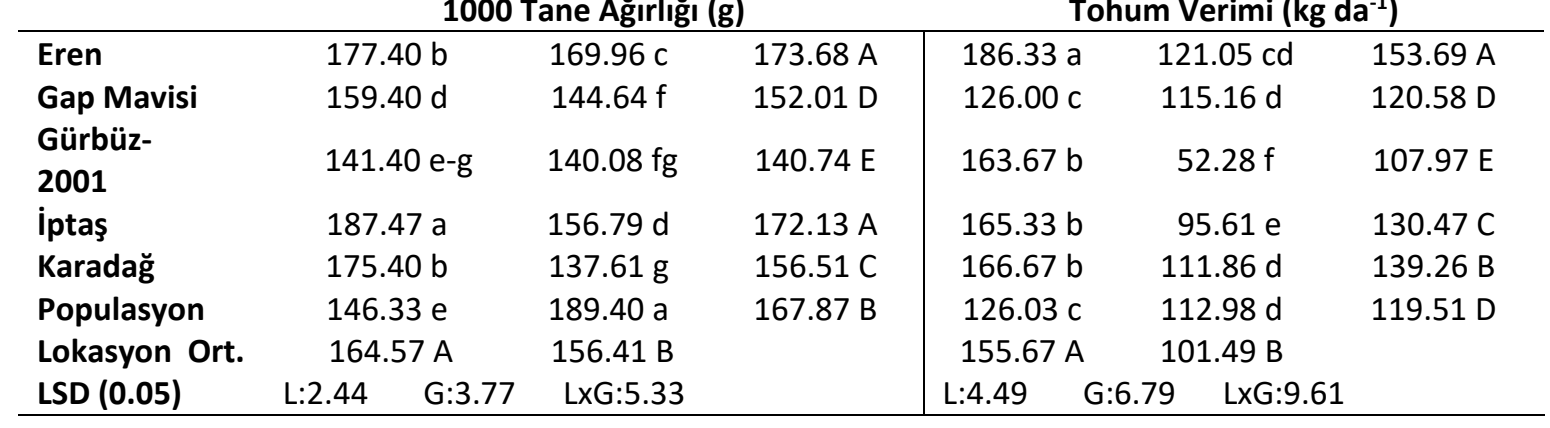

\begin{tabular}{llll|lll} 
& \multicolumn{3}{c}{ Ham Protein Oranı (\%) } & \multicolumn{2}{c}{ Ham Protein Verimi (kg da-1) } \\
\hline Eren & $23.23 \mathrm{~d}$ & $22.76 \mathrm{~d}$ & $22.99 \mathrm{C}$ & $43.30 \mathrm{a}$ & $27.53 \mathrm{~d}$ & $35.42 \mathrm{~A}$ \\
Gap Mavisi & $22.68 \mathrm{~d}$ & $23.09 \mathrm{~d}$ & $22.89 \mathrm{C}$ & $28.62 \mathrm{~d}$ & $26.61 \mathrm{~d}$ & $27.62 \mathrm{D}$ \\
Gürbüz- & $25.26 \mathrm{bc}$ & $23.28 \mathrm{~d}$ & $24.27 \mathrm{AB}$ & $41.35 \mathrm{ab}$ & $12.18 \mathrm{f}$ & $26.76 \mathrm{D}$ \\
$\mathbf{2 0 0 1}$ & & & & & & \\
İptaş & $26.73 \mathrm{ab}$ & $22.87 \mathrm{~d}$ & $24.80 \mathrm{AB}$ & $44.17 \mathrm{a}$ & $21.86 \mathrm{e}$ & $33.01 \mathrm{~B}$ \\
Karadağ & $23.69 \mathrm{~d}$ & $23.91 \mathrm{~cd}$ & $23.80 \mathrm{BC}$ & $39.48 \mathrm{~b}$ & $26.75 \mathrm{~d}$ & $33.12 \mathrm{AB}$ \\
Populasyon & $28.05 \mathrm{a}$ & $22.47 \mathrm{~d}$ & $25.26 \mathrm{~A}$ & $35.36 \mathrm{c}$ & $25.41 \mathrm{~d}$ & $30.39 \mathrm{C}$ \\
Lokasyon Ort. & $24.94 \mathrm{~A}$ & $23.06 \mathrm{~B}$ & & $38.71 \mathrm{~A}$ & $23.39 \mathrm{~B}$ & G:2.38 LxG:3.64 \\
LSD (0.05) & L:0.60 G:1.09 & LxG:1.55 & & L:1.53 & G G
\end{tabular}

*: Aynı harfleri taşıyan ortalamalar arasındaki fark önemli değildir ( $P<0.05)$ (LSD)

Sonuç ve Öneriler

Farklı iki lokasyonda yapılan bu çalışmada; ot verimi ve kalitesi açısından değerlendirme yapılacak olursa her iki lokasyonda da Eren ve İptaş çeşitlerinin öne çıktığı, ayrıca Bursa lokasyonunda köy popülasyonunun da ümitvar olduğu görülmüştür. Tohum verimi ve kalitesi değerlerine bakıldığında da yine her iki lokasyonda Eren çeşidinin en iyi sonuçları verdiği ve Bilecik lokasyonunda İptaş ile Gürbüz-2001, Bursa loksyonunda da Gap Mavisi ve Karadağ çeşitleri ile köy popülasyonunun kaliteli bir ürün elde edilmek istenildiğinde düşünülmesi gereken genotipler olduğu görülmüştür. Ayrıca ileride yapılacak ıslah çalışmalarında; özellikle yüksek verimli tohum elde etmek için köy popülasyonunun mutlak suretle faydalanılması gerektiği kanaatine varılmıştır.

\section{Kaynaklar}

Acar, Z., Ayan, I. ve Genç, N. 1997. Samsun koşullarında yüzlek eğlimli arazilerde yetiştirilen Mürdümük hat ve populasyonlarının ot verimi ve bazı özelliklerinin belirlenmesi. Türkiye 2 . Tarla Bitkileri Kongresi, Samsun, s. 441445. 
Anonim 2018. T.C. Başbakanlık Devlet Meteoroloji İşleri Genel Müdürlüğü, Bilecik ve Bursa il Md. Kayıtları.

Arevalo, L.S., Oosterhuis, D.M., Coker, D. ve Brown, R.S. 2008. Physiological response of cotton to high night temperature. Physiological Response of Cotton to High Temperatures 2:6368.

Arslan, M. 2016. Türkiye'de yem bitkileri üretiminde yaygın mürdümüğün (Lathyrus sativus L.) önemi ve mevcut durumu. Türk Tarım ve Doğa Bilimleri Dergisi 3(1): 17-23.

Barnes R.F., Nelson, J.C., Collins, M. ve Moore, K.J. 2003. Forages, an introduction to grassland agriculture (6. Ed.), lowa State Press, Blackwell Publishing Company Ames, lowa, USA.

Başaran, U., Mut,.H., Aşci, Önal, Ö., Acar, Z. ve Ayan, i. 2011. Variability in forage quality of Turkish grass pea (Lathyrus sativus L.) landraces. Turkish Journal of Field Crops, 16 (1): 9-14.

Bayram, G., Türk, M., Budaklı, E. ve Çelik, N. 2004. Bursa ekolojik koşullarında yetiştirilen yaygın mürdümük (Lathyrus sativus L.) hatlarının verim ve adaptasyonu üzerinde bir araştırma. Uludağ Üniversitesi Ziraat Fakültesi Dergisi, 18 (2), 73-84.

Karadağ, Y. ve Yavuz, M. 2010. Seed yields and biochemical compounds of grasspea (Lathyrus sativus L.) lines grown in semi-arid regions of Turkey. African Journal of Biotechnology, 9(49): 83438348.

Karadağ, Y., Yavuz, M., Karaalp, M., Akbay, S. ve Kır, H. 2011. Bazı mürdümük (Lathyrus sativus L.) hatlarının Tokat-Kazova ekolojik koşullarında verim ve kalite özelliklerinin belirlenmesi. Türkiye $1 \mathrm{X}$. Tarla Bitkileri Kongresi, 12-15 Eylül, s. 1625-1630.

Karadağ, Y., Özkurt, M., Akbay, S. ve Kır, H. 2012. Tokat-Kazova ekolojik koşullarında bazı mürdümük (Lathyrus sativus L.) hatlarının verim ve verim özelliklerinin belirlenmesi. Tarım Bilimleri Araştırma Dergisi, 5 (2): 11-13.

Kosev, V. ve Vasileva, V. 2018. Biochemical assessment of grass pea (Lathyrus sativus L.) varieties. Journal of Global Innovations in Agricultural and Social Sciences, 6(1):23-27.
Kökten, K. ve Tansı, V. 2004 Çukurova koşullarında mürdünıük (Lathyrus sativus L.) ile değişik tahıl türleri karışım oranlarının verim ve kaliteye etkisi . Çukurova Üniversitesi Ziraat Fakültesi Dergisi, 19 (4): 69-76.

Kökten, K., ve Bakoğlu, A. 2011. Elazığ koşullarında mürdümük (Lathyrus sativus L.)'te farklı sıra arasının tohum verimi ve verim öğeleri üzerine etkisi. Bingöl Üniversitesi Fen Bilimleri Enstitüsü Dergisi, 1(1): 37-42.

Larbi, A., El-Moneim, A., Nakkoul, H., Jammal, B. ve Hassan, S. 2010. Intra-species variations in yield and quality in lathyrus species: 1 . grasspea ( $L$. sativus L.). Animal Feed Science and Technology, 161: 9-18.

Loka, D., ve Oosterhuis, D.M. 2010. Effects of high night temperature on cotton respiration, ATP levels and carbohydrate content. Environmental and Experimental Botany, 68:258263.

Mihailovic, V. Mikic, A. Cupina, B. Krstic, D. Antanasovic, S. ve Radojevic, V. 2013. Forage yields and forage yield compositions in grass pea (Lathyrus sativus L.). Legume Research, 36(1): 67-69.

Mikic, A., Mihailovic, V., C'upina, B. Krstic, D., Vasiljevi'c, S. ve Mili'c, D. 2010. Forage and seed yield components in four french landraces of grass pea (Lathyrus sativus L.). Sustainable Use of Genetic Diversity in Forage and Turf Breeding. (ed.) Huyghe C., 127-130.

Milczak, M., Pedinski, M., Mnicfiowska, H., Szwed-Urbas, K. ve Rybinski, W. 2001. Creative breeding of Graaspea (Latyrus sativus L.) in Poland. Latyrus lattıyrism Newsletter, 2, 85-88.

Öten, M., Kiremitci, S. ve Erdurmuş, C. 2017. Mürdümükte (Lathyrus sativus L.) tane ve kuru ot verimi ile ilişkili özelliklerin korelasyon ve path analizi ile saptanması. Derim, 34 (1):72-78.

Rosa, M.J.S., Ferreira, F.B. ve Teixeira, A.R. 2000. Storage proteins from Lathyrus sativus seeds. Journal of Field Crops, 48: 4432-5439.

Sabancı, C.O., Kır, H., Yavuz, T., Karayel, A. İ. ve Başköy, S. 2016. Farklı sıra arası uygulamalarının mürdümük (Lathyrus sativus L.) ot verimi ve kalitesine 
etkisi. Anadolu, Journal of Aegean Agricultural Research Institute, 26(2): 1-13.

Sağsöz, S. 1990. Tohumluk Bilimi. Atatürk Üniversitesi Yayınları No:677. Ziraat Fakültesi Yayınları No:302. Ders Kitapları Serisi No: 54, Erzurum.

Sayar, M.S., Han, Y., Seydoşoğlu, M. ve Başbağ, M. 2013. Diyarbakır ekolojik koşullarında bazı mürdümük (Lathyrus sativus L.) hatlarının ot verimi, ot verimini etkileyen özellikler ile özellikler arası ilişkilerin belirlenmesi. Türkiye $X$. Tarla Bitkileri Kongresi, 10-13 Eylül , III. Cilt, s. 5664.

Sayar, M.S. ve Han, Y. 2015. Mürdümük (Lathyrus sativus L.) hatlarının tohum verimi ve verim komponentlerinin belirlenmesi ve GGE biplot analiz yöntemiyle değerlendirilmesi. Tarım Bilimleri Dergisi- Journal of Agricultural Sciences, 21(1): 78-92.

Seydoşoğlu, S., Saruhan, V., Kökten, K. ve Karadağ, Y. 2015. Diyarbakır ekolojik koşullarında bazı mürdümük (Lathyrus sativus L.) genotiplerinin verim ve verim unsurlarının belirlenmesi. Gaziosmanpaşa Üniversitesi Ziraat Fakültesi Dergisi, 32(3):98-109.

TUik 2018. Türkiye İstatistik Kurumu Bitkisel Üretim Verileri. (https://biruni.tuik.gov.tr)

Turan, Z.M. 1995. Araştırma ve Deneme Metotları. Uludağ Üniversitesi Ziraat Fakültesi Ders Notları, Bursa, $302 \mathrm{~s}$.

Urga, K., Fufa, H., Biratu, E. ve Husain, A. 2005. Evaluation Lathyrus sativus culivated in Ethiopia for proximate composition, minerals, â-odap and anti-nutritional components. African Journal of Food Agriculture and Nutritional Development, 5(1):1-15.

Van Soest, P.J. 1994. Nutritional ecology of the ruminant (2. ed.). Cornell University Press, Ithaca, N.Y., 528 p.

VazPatto, M.C., Skiba, B., Pang, E.C.K., Ochatt, S.J., Lambein, F. ve Rubiales, D. 2006. Lathyrus improvement for resistance against biotic and abiotic stresses: From classical breeding to marker assisted selection. Euphytica, International Journal of Plant Breeding, 147: 133-147.
Yavuz, M. 2005. Bazı ruminant yemlerinin nispi yem değeri ve in vitro sindirim değerlerinin belirlenmesi. Gaziosmanpaşa Üniversitesi Ziraat Fakültesi Dergisi, 22 (1): 97-101. 